\title{
New particle formation in air mass transported between two measurement sites in Northern Finland
}

\author{
M. Komppula ${ }^{1}$, S.-L. Sihto ${ }^{2}$, H. Korhonen ${ }^{1}$, H. Lihavainen ${ }^{1}$, V.-M. Kerminen ${ }^{1}$, M. Kulmala ${ }^{2}$, and Y. Viisanen ${ }^{1}$ \\ ${ }^{1}$ Finnish Meteorological Institute, Research and Development, P. O. Box 503, 00101 Helsinki, Finland \\ ${ }^{2}$ University of Helsinki, Dept. Physical Sciences, P. O. Box 64, 00014 Univ. of Helsinki, Finland
}

Received: 5 October 2005 - Published in Atmos. Chem. Phys. Discuss.: 22 November 2005

Revised: 9 March 2006 - Accepted: 15 June 2006 - Published: 10 July 2006

\begin{abstract}
This study covers four years of aerosol number size distribution data from Pallas and Värriö sites $250 \mathrm{~km}$ apart from each other in Northern Finland and compares new particle formation events between these sites. In air masses of eastern origin almost all events were observed to start earlier at the eastern station Värriö, whereas in air masses of western origin most of the events were observed to start earlier at the western station Pallas. This demonstrates that particle formation in a certain air mass type depends not only on the diurnal variation of the parameters causing the phenomenon (such as photochemistry) but also on some properties carried by the air mass itself. The correlation in growth rates between the two sites was relatively good, which suggests that the amount of condensable vapour causing the growth must have been at about the same level in both sites. The condensation sink was frequently much higher at the downwind station. It seems that secondary particle formation related to biogenic sources dominate in many cases over the particle sinks during the air mass transport between the sites. Two cases of transport from Pallas to Värriö were further analysed with an aerosol dynamics model. The model was able to reproduce the observed nucleation events $250 \mathrm{~km}$ down-wind at Värriö but revealed some differences between the two cases. The simulated nucleation rates were in both cases similar but the organic concentration profiles that best reproduced the observations were different in the two cases indicating that divergent formation reactions may dominate under different conditions. The simulations also suggested that organic compounds were the main contributor to new particle growth, which offers a tentative hypothesis to the distinct features of new particles at the two sites: Air masses arriving from the Atlantic Ocean typically spent approximately only ten hours over land before arriving at Pallas, and thus the time for the organic vapours to accumulate in the air and
\end{abstract}

Correspondence to: M. Komppula

(mika.komppula@fmi.fi) to interact with the particles is relatively short. This can lead to low nucleation mode growth rates and even to suppression of detectable particle formation event due to efficient scavenging of newly formed clusters, as was observed in the case studies.

\section{Introduction}

Atmospheric aerosol particles have large impacts on the global cloud albedo, radiative forcing, ozone layer, acid rain and visibility (Seinfeld and Pandis, 1998; Jacobson, 2001; Lohmann and Feichter, 2005). Uncertainties in the estimation of direct and indirect aerosol effects on the global climate are large. These uncertainties are greatly due to the lack of information on the spatial and temporal distribution and optical properties of aerosol particles, as well as due to our poor understanding on how aerosol particles interact with clouds (Adams and Seinfeld, 2002; Kaufman et al., 2002).

New particle formation is a major research issue in atmospheric sciences. Particle formation increases the total number concentration of ambient submicron particles and may contribute to the climate forcing. Earlier measurements in Northern Finland have shown that atmospheric new particle formation can be a significant source of ultrafine $(<100 \mathrm{~nm})$ particles (Lihavainen et al., 2003; Vehkamäki et al., 2004; Kerminen et al., 2005). It has also been observed that ultrafine particles have a significant influence on cloud droplet activation under clean and moderately polluted conditions, being therefore important when estimating the indirect climatic effects by aerosols (Komppula et al., 2005). Since atmospheric new particle formation is observed in most atmospheric environments (Kulmala et al., 2004a), it is important to find out its global contribution to indirect climatic effects. Formation and growth mechanisms of aerosol particles are still not fully understood. The geographical extent of particle formation events and conditions affecting these events are

Published by Copernicus GmbH on behalf of the European Geosciences Union. 


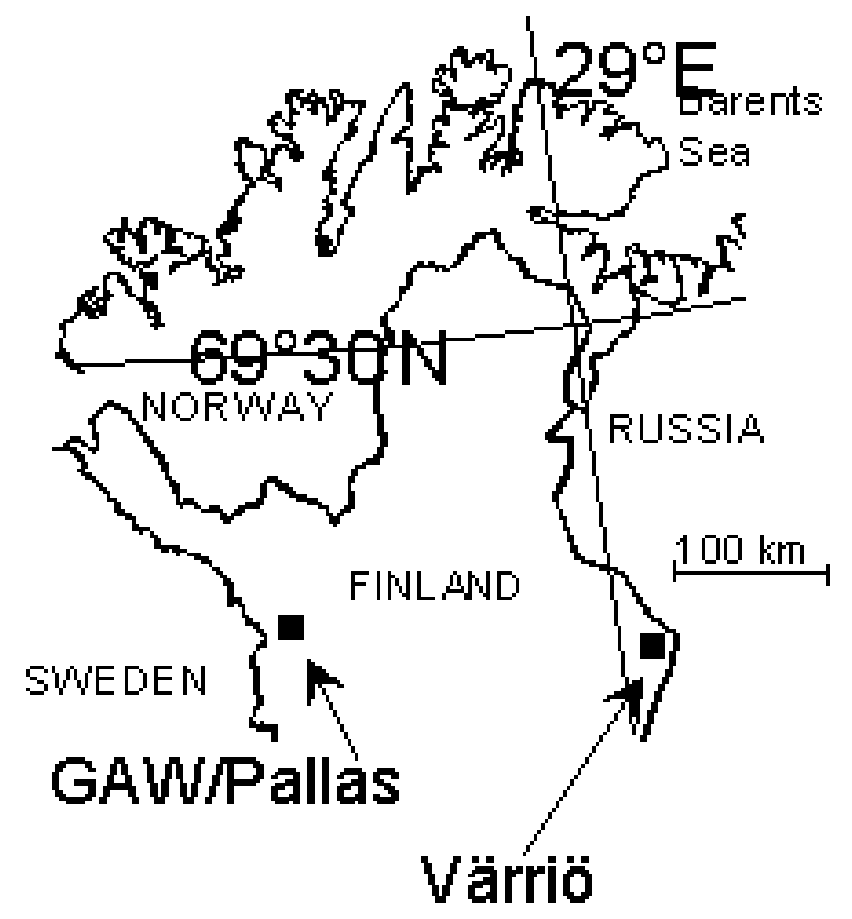

Fig. 1. Location of the measurement sites, Pallas and Värriö.

not well known, though some progress has been made (Kulmala et al., 2004a). In Northern Finland, there are two stations, Pallas and Värriö, which are separated from each other by $250 \mathrm{~km}$ and have a similar kind of instrumentation for aerosol particle measurements. This gives us a good opportunity to investigate the similarities and difference in particle formation events between the two sites, the geographical extent of this phenomenon and the influence of atmospheric conditions on it. The effect of particle sources and sinks between the two sites can be investigated.

This study covers four years of data from Pallas and Värriö and compares new particle formation events between these sites. A seasonal variation of some parameters related to new particle formation is presented. The effects of the air mass origin and transport direction on particle formation and its intensity are studied. Main parameters related to particle formation are compared between the two sites. An effort is made to model new particle formation in the Värriö site based on size distributions measured in the Pallas site. Modelling results are presented as two case studies. Our investigations were related to the LAPBIAT-project, particularly the campaign performed in Värriö SMEAR I station in April-May, 2003.

\section{Materials and methods}

\subsection{Site description}

Both stations, Pallas and Värriö, are located in a subarctic region in Northern Finland (Fig. 1). There are practically no local sources of pollutants close to the stations. The closest major pollutant sources are the smelters in Nikel and Montshegorsk in Kola Peninsula, Russia, located $200 \mathrm{~km}$ to the north and $140 \mathrm{~km}$ to the east of the Värriö station, respectively.

The main measuring site at Pallas GAW (Global Atmosphere Watch) station, Sammaltunturi $\left(67^{\circ} 58^{\prime} \mathrm{N}, 24^{\circ} 07^{\prime} \mathrm{E}\right.$, WMO index number 05821), lies on a top of a fjeld (arctic round-topped hill) at the height of $565 \mathrm{~m}$ above the sea level (a.s.l.), and ca $300 \mathrm{~m}$ above the surrounding area. The tree line is some $100 \mathrm{~m}$ below the station. The surrounding forest is mixed pine, spruce and birch. The vegetation on the top of the fjeld is sparse, consisting mainly of low vascular plants, moss and lichen. The station is within the Pallas-Ounastunturi National Park (total area $501 \mathrm{~km}^{2}$ ) near the northern limit of the boreal forest zone. A detailed description on the site is given in Hatakka et al. (2003).

The Värriö environmental measurement station SMEAR I $\left(67^{\circ} 46^{\prime} \mathrm{N}, 2^{\circ} 35^{\prime} \mathrm{E}\right)$ (Hari et al., 1994; Ahonen et al., 1997) is located 250 kilometres away and almost directly to the east of Pallas. The station is ten kilometres away from the Russian border at the height of $390 \mathrm{~m}$ a.s.l. The station is located just below the alpine timber line, which is about $400 \mathrm{~m}$ a.s.l. The main tree species in the area is Scots pine. The station area belongs to the Värriö National Park.

\subsection{Measurements}

Similar DMPS (Differential Mobility Particle Sizer) systems were used at both measuring sites for nanometre particle sizing. The DMPS systems consist of a $28-\mathrm{cm}$ long Hauketype differential mobility analyzer (DMA) (Winklmayr et al., 1991) with a closed loop sheath flow arrangement (Jokinen and Mäkelä, 1997) and a condensation particle counter (CPC), TSI model 3010. The closed loop sheath air is dried with a silica gel dryer and the relative humidity is kept below 20\%. This sheath air setup keeps also the temperature more constant. Before sizing, the aerosol is neutralized with a radioactive source. The used sheath air flow rate is about $111 \mathrm{~min}^{-1}$ and the sample aerosol flow rate is $11 \mathrm{~min}^{-1}$. The measured particle size range is from 7 to $500 \mathrm{~nm}$, which is divided into 30 discrete bins at Pallas and 20 bins at Värriö. Size distribution measurements at Värriö were extended to cover a size range from $3 \mathrm{~nm}$ to $500 \mathrm{~nm}$, using 24 size bins on 26 April 2003. This was done by using a Twin-DMPS system (e.g. Kulmala et al., 2001).

Basic weather parameters and a number of trace gases were measured. Temperature, pressure, relative humidity, wind speed and global radiation were measured at both stations. At Pallas there was a rain intensity sensor and at Värriö 
an on/off-type rain sensor. Visibility measurements at Pallas have revealed the occasional presence of fog or low clouds at the station (Komppula et al., 2003a; Komppula et al., 2005). $\mathrm{NO}_{\mathrm{x}}$ and $\mathrm{SO}_{2}$ concentrations were measured at both stations. One-hour averages of these gas concentrations were used in the analyses.

The new DMPS data analysed in this article covered a period of 24 months, years 2002 and 2003. In the analysis of different air masses also data from previously analysed years 2000-2001 was used. Various parameters describing the new particle formation events, including trace gas concentrations and weather-related parameters were compared. 120-h backward trajectories were calculated by FLEXTRA (Stohl et al., 1995) and Hysplit 4 (Draxler and Rolph, 2003) to find the origin and the path of the air masses. FLEXTRA trajectories were calculated for every three hours for both sites.

\subsection{Identification of particle formation events}

A new particle formation event can be visualized with a surface plot, in which the submicron particle size distribution is presented as a function of time (Mäkelä et al., 1997; Kulmala et al., 1998). An event is seen as increasing particle concentrations in smallest size channels of the DMPS system. On a typical particle formation day, newly-formed particles enter the measurement range at around midday at initial sizes below $15 \mathrm{~nm}$. During the rest of the day subsequent growth of these particles is seen at a rate of a few nanometres per hour. Events are classified according to their intensity into three classes. Class 1 events have intense formation of new particles and distinct particle growth for hours during the rest of the day. Class 2 events are not that intense or the subsequent growth is not as clear but still these main features can be recognized. Class 3 events lack the clear growth or only few new particles are formed. Classifying between a particle formation event and non-event is sometimes difficult and somewhat subjective. The classification method applied here has been explained in more detail by Mäkelä et al. (2000).

Particle formation events were observed from daily surface plots by visually searching for sudden increases in the number of smallest particles and subsequent growth. The event-specific averages over each event were estimated from the size distributions for the particle formation rate (particles $\left.\mathrm{cm}^{-3} \mathrm{~s}^{-1}\right)$ and particle growth rate $\left(\mathrm{nm} \mathrm{h}^{-1}\right)$. Particle formation days were mainly examined with a program made for this purpose at the University of Helsinki (Mäkelä et al., 2000). The starting and ending times of the events and the number of new particles formed during the event were analysed. Defining the starting and ending times for an event is sometimes difficult due to fluctuations in the smallest size classes of the measurement system and due to measurement uncertainties. The presence of pre-existing particles affecting the condensation sink (CS) just before the formation event was also a point of interest. The condensation sink determines how rapidly molecules condense onto pre-existing aerosols and depends strongly on the shape of the particle size distribution (Pirjola et al., 1999). A detailed calculation procedure for the condensation sink has been presented by Kulmala et al. (2001). The condensable vapour concentration required for the observed average particle growth rate during each particle formation event was estimated. In addition the source rate of condensable vapour required to sustain the observed growth was estimated for each event as presented by Kulmala et al. (2001).

\subsection{Simulation setup}

The size-segregated aerosol dynamics model UHMA (University of Helsinki Multicomponent Aerosol model) (Korhonen et al., 2004) can be used for Lagrangian studies of the tropospheric aerosol particles. The model includes the major clear sky processes: multicomponent condensation of organic and inorganic species (Grini et al., 2005), coagulation, new particle formation through nucleation and primary emissions, dry deposition as well as a simple treatment of entrainment and detrainment. Recently the model has been extended to treat cloud processing in non-precipitating clouds (Korhonen et al., 2005).

In the current study, the model was applied to two case studies to investigate nucleation and particle growth in air masses travelling from Pallas to Värriö measurement site. The air mass trajectory information was obtained from NOAA ARL trajectory model Hysplit 4 (Draxler and Rolph, 2003). The meteorological conditions (temperature, pressure, relative humidity, boundary layer height) for the model were interpolated from the calculated trajectory data. The particle size distribution and $\mathrm{SO}_{2}$ concentration measured at Pallas were used as model input and the modelled results were compared to similar measurements made at Värriö. The nucleation rate of particles and the concentration profile of condensable organic vapours, neither of which is directly available from measurements, were treated as follows.

In boreal forest conditions, organic compounds dominate the growth of the nucleation mode particles while condensation of sulphuric acid has been estimated to explain only about $10 \%$ of new particle growth rate (Boy et al., 2005). So far the knowledge of the chemical identity of the lowvolatile organics responsible for particle growth is quite limited; however, it is likely that in boreal forest these lowvolatile organics are oxidation products of forest-emitted species, such as terpenes (Kavouras et al., 1998) or isoprene (Kourtchev et al., 2005). Since the exact oxidation mechanisms of the condensable products are unknown, we tested several possible production profiles which either remained constant throughout the day or followed the diurnal concentration of the atmospheric oxidants. For the saturation concentration of the condensable organic vapour we assumed a value $10^{6} \mathrm{~cm}^{-3}$, which has been suggested by Kulmala et al. (2004b) based on modelling studies of new particle formation in boreal forests. The onset of the condensation of 


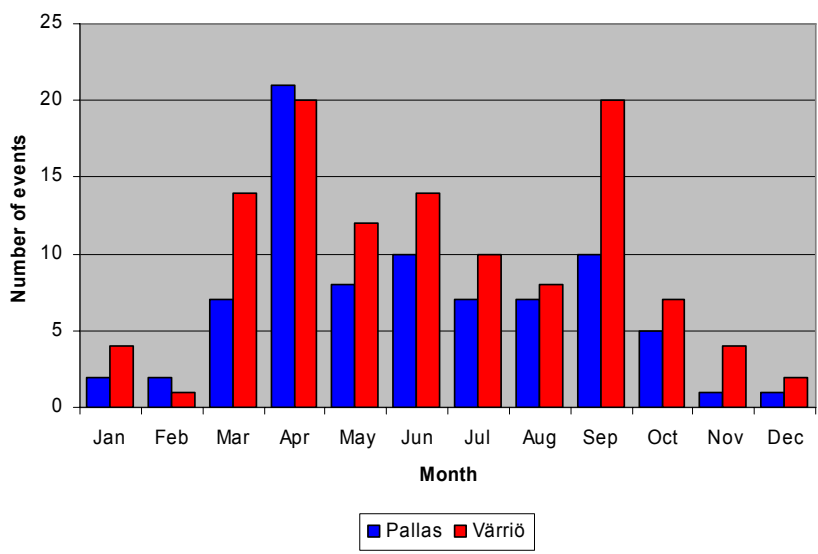

Fig. 2. Monthly distribution of all new particle formation events observed in Pallas and in Värriö during years 2002-2003.

the organic compound followed the nano-Köhler mechanism suggested by Kulmala et al. (2004b).

Sulphuric acid concentration was calculated from measured $\mathrm{SO}_{2}$ concentrations (measurements both at Pallas and Värriö stations) and estimated $\mathrm{OH}$ concentrations. The maximum concentration of sulphuric acid obtained from this procedure was $1-6 \times 10^{6} \mathrm{~cm}^{-3}$, corresponding well with measurements made at other rural or remote locations (Weber et al., 1997; Birmili et al., 2003; Mauldin et al., 2003; Boy et al., 2005). We calculated also the total concentration of condensing vapours (sulphate and organics) from the measured growth rate based on the expression presented by Kulmala et al. (2001), and the maximum of the organic vapour concentration in the simulations was adjusted accordingly.

Based on a review of an extensive set of field measurements, Kulmala et al. (2004a) concluded that sulphuric acid is a very likely candidate to take part in tropospheric nucleation. The exact nucleation mechanism remains, however, unidentified and therefore we described nucleation in our simulations by simply scaling the kinetic rate of nucleation, i.e. the collision rate between two ammonium bisulphate molecules, to produce the observed intensity of the new particle formation event. While this procedure does not directly correspond to any specific physical nucleation mechanism, it enables comparison between the studied cases as it relates the nucleation rate to the calculated sulphuric acid concentration.

\section{Results and discussion}

In total close to four years of data on new particle formation events at Pallas and Värriö were studied. A seasonal variation of parameters related to new particle formation is presented. The effects of the air mass origin on particle formation and its intensity are studied. A comparison between the two sites is presented concerning the main parameters related to particle formation in air masses of eastern and western origin. One of the ideas of this study was to find out whether the physical properties of aerosol particles observed at the Värriö station can be generated from those observed at the Pallas station, or if something is taking place that we cannot explain. An effort is made to model new particle formation in the Värriö site based on size distributions measured in the Pallas site. Modelling results are presented as two case studies.

\subsection{Data analysis}

\subsubsection{Previous studies}

In our earlier study (Komppula et al., 2003b), a comparison between the sites was done with a dataset of 21 months (April 2000-December 2001). More than half (55\%) of the new particle formation events were observed to occur at both sites during the same day. Most of the days when an event was observed at one of the sites only could be explained by pollution plumes, weather differences (mostly rain/fog) or by different air mass origins. The largest differences and variation were seen in the starting times of the events. Average particle formation and growth rates were found to be similar at both sites. According to the trajectory analysis, all events were associated with marine/polar air masses originating from the Northern Atlantic or the Arctic Ocean. It was also concluded that about one third of the events at Värriö were associated with plumes from the Kola Peninsula industry, and it appears likely that some of these events were caused by nucleation involving $\mathrm{H}_{2} \mathrm{SO}_{4}$ from $\mathrm{SO}_{2}$ oxidation in these industry plumes. On some days Pallas experienced also air masses from the Kola area, but it seems that the much longer distance from Kola to Pallas reduces the $\mathrm{SO}_{2}$ concentrations to lower levels than what is needed to launch the nucleation process at Pallas. Overall the simultaneous events indicated that in clean air masses the geographical extent of a nucleation event could be at least $250 \mathrm{~km}$, which is the distance between the Pallas and Värriö stations.

Vehkamäki et al. (2004) studied particle formation events in Värriö during the period 1998-2002. They found in total 147 clear new particle formation events. As expected the frequency of occurrence was highest in spring (March-May). They found also that the particle formation and growth rates were uncorrelated. The growth rate was found to be highest during summer and lowest in winter. No seasonal variation in the formation rate was observed. The plumes from Kola industrial area were observed to result in higher formation rates but had no effect on the growth rate.

\subsubsection{Additional new data - years 2002 and 2003}

A new data period of 24 months (years 2002-2003) was taken to make a new comparison between the sites and furthermore to be combined with the earlier data (years 2000- 
Table 1. Seasonal variation and annual average values of some parameters related to class 1 and 2 new particle formation events observed during the years 2002-2003 in Pallas and in Värriö. (Winter values in Pallas are left out due to poor statistics). The formation and growth rate, condensation sink, vapour concentration and source rate are calculated from event-averages and then grouped according to season.

\begin{tabular}{|c|c|c|c|c|c|c|c|c|c|}
\hline & $\begin{array}{l}\text { Starting } \\
\text { time }^{\mathrm{a}} \\
\text { (hh:mm) }\end{array}$ & $\begin{array}{l}\text { Existing } \\
\text { conc. }^{\mathrm{b}} \\
\left(\mathrm{cm}^{-3}\right)\end{array}$ & $\begin{array}{l}\text { Duration }^{\mathrm{c}} \\
\text { (hh:mm) }\end{array}$ & $\begin{array}{l}\text { Formation } \\
\text { rate }^{\mathrm{d}} \\
\left(\mathrm{cm}^{-3} \mathrm{~s}^{-1}\right)\end{array}$ & $\begin{array}{l}\text { Growth } \\
\text { rate }^{\mathrm{e}} \\
\left(\mathrm{nm} \mathrm{h}^{-1}\right)\end{array}$ & $\begin{array}{l}\text { Particles } \\
\text { produced }^{\mathrm{f}} \\
\left(\mathrm{cm}^{-3}\right)\end{array}$ & $\begin{array}{l}\text { Cond. sink }{ }^{\mathrm{g}} \\
\left(10^{-4} \mathrm{~s}^{-1}\right)\end{array}$ & $\begin{array}{c}\text { Vapour } \\
\text { conc. }^{\mathrm{h}} \\
\left(10^{7} \mathrm{~cm}^{-3}\right)\end{array}$ & $\begin{array}{c}\text { Vapour } \\
\text { source rate } \\
\left(10^{4} \mathrm{~cm}^{-3} \mathrm{~s}^{-1}\right)\end{array}$ \\
\hline \multicolumn{10}{|l|}{ PALLAS } \\
\hline Winter & - & - & - & - & - & - & - & - & - \\
\hline Spring & $11: 50$ & 690 & $04: 20$ & 0.10 & 2.7 & 1270 & 8.3 & 4.4 & 3.9 \\
\hline Summer & 09:30 & 360 & $04: 40$ & 0.09 & 4.5 & 1480 & 6.5 & 7.3 & 6.0 \\
\hline Autumn & $12: 10$ & 360 & 04:00 & 0.07 & 3.1 & 970 & 3.9 & 5.0 & 2.0 \\
\hline Mean & $11: 20$ & 570 & $04: 20$ & 0.09 & 3.1 & 1280 & 7.4 & 5.1 & 4.2 \\
\hline \multicolumn{10}{|l|}{ VÄRRIÖ } \\
\hline Winter & $12: 40$ & 440 & $03: 10$ & 0.10 & 2.5 & 1180 & 1.2 & 4.2 & 0.5 \\
\hline Spring & $11: 20$ & 1000 & $03: 50$ & 0.21 & 3.1 & 2310 & 11.5 & 5.2 & 7.3 \\
\hline Summer & $10: 40$ & 780 & $03: 30$ & 0.19 & 5.2 & 2320 & 9.1 & 8.6 & 9.0 \\
\hline Autumn & $11: 20$ & 310 & $04: 40$ & 0.09 & 2.2 & 1350 & 6.1 & 3.5 & 2.1 \\
\hline Mean & $11: 10$ & 850 & 03:50 & 0.19 & 3.7 & 2190 & 9.9 & 6.1 & 7.1 \\
\hline
\end{tabular}

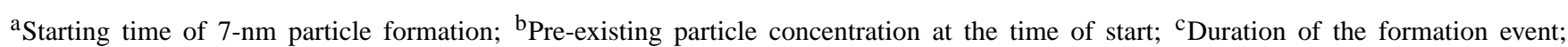
${ }^{\mathrm{d}}$ Formation rate of 7 -nm particles; ${ }^{\mathrm{e}}$ Growth rate of newly formed particles; ${ }^{\mathrm{f}} \mathrm{New}$ particles produced during the event; ${ }^{\mathrm{g}}$ Condensation sink for vapour by existing particles; ${ }^{\text {h }}$ Vapour concentration needed for the observed growth; ${ }^{i}$ Vapour source rate needed to sustain the growth.

2001) in comparison of air mass differences. During years 2002-2003, 116 particle formation events were observed in Värriö and 81 events in Pallas. In $62 \%$ of all the event days at least some indication of particle formation was observed at both sites. This is in agreement with our previous study. The highest frequency of events occurred in April and September (Fig. 2). Table 1 presents the seasonal variation related to class 1 and 2 new particle formation events observed during the years 2002-2003. Average values seem to be slightly higher in Värriö. Värriö had a slightly higher growth rate on average. The formation rate of 7-nm particles in Värriö was two times the value observed in Pallas. In Värriö more new particles were produced during the events on average. Värriö had also slightly higher pre-existing particle concentrations and CS. All this means that in Värriö a higher concentration and higher source rate of condensable vapour is needed. Overall, the values are of about the same magnitude as observed in the earlier studies.

Seasonal variations of some parameters related to observed class 1 and 2 particle formation events are presented in Table 1. The starting time of particle formation $(7 \mathrm{~nm}$ particles) was earliest in summer, following the annual pattern of sun rise. All class 1 and 2 events were observed to start between 07:00 and 16:40. The duration of these events seemed to have no seasonal pattern. The formation rate of $7 \mathrm{~nm}$ particles had no clear seasonal variation, though higher average values were observed in spring and summer in Värriö. A reasonable explanation for the higher values from March to July in Värriö would be the more frequent air masses from Kola industrial area. Observed formation rates varied between 0.01 and $0.98 \mathrm{~cm}^{-3} \mathrm{~s}^{-1}$. The growth rate had a similar seasonal pattern at both sites. The highest growth rates were observed during summer. Growth rates varied from 0.1 to $9.0 \mathrm{~nm} \mathrm{~h}^{-1}$. The production of new particles per event was highest in spring and summer at both sites. The condensation sink (and the pre-existing particle concentration) had slightly higher values in spring and summer. This together with higher growth rates leads to higher vapour source rate needed in spring and summer. CS varied from 0.4 to $40 \times 10^{-4} \mathrm{~s}^{-1}$ and the vapour source rate from 0.2 to $60 \times 10^{4} \mathrm{~cm}^{-3} \mathrm{~s}^{-1}$.

\subsubsection{Particle formation in air masses of eastern and west- ern origin passing the two sites}

In this analysis the whole four-year data set was used to get reasonable statistics. Air mass backward trajectories (120 h) were calculated for every $3 \mathrm{~h}$ for both sites. By using this set of trajectories, we selected all the cases in which the air had passed the Pallas site within $50 \mathrm{~km}$ in maximum prior to entering Värriö (western air masses), as well as cases describing the air mass transport from Värriö to Pallas (eastern air masses).

A comparison of different parameters related to particle formation between the two sites in both western and eastern air masses is presented in Fig. 3. Altogether, 31 particle formation events took place in western air masses and 7 events took place in eastern air masses. In eastern air masses almost all events were observed to start earlier at the eastern station Värriö, whereas in western air masses most of the 
Table 2. Some parameters related to particle formation events observed on the same day at both sites during years the 2000-2003 classified by the air mass origin. The formation and growth rate, condensation sink, vapour concentration and source rate are calculated from eventaverages and then grouped according to air mass and location.

\begin{tabular}{|c|c|c|c|c|c|c|c|c|c|}
\hline & $\begin{array}{l}\text { Starting } \\
\text { time }^{\mathrm{a}} \\
\text { (hh:mm) }\end{array}$ & $\begin{array}{l}\text { Existing } \\
\text { conc. } \\
\left(\mathrm{cm}^{-3}\right)\end{array}$ & $\begin{array}{l}\text { Duration }^{\mathrm{c}} \\
\text { (hh:mm) }\end{array}$ & $\begin{array}{l}\text { Formation } \\
\text { rate }^{\mathrm{d}} \\
\left(\mathrm{cm}^{-3} \mathrm{~s}^{-1}\right)\end{array}$ & $\begin{array}{c}\text { Growth } \\
\text { rate }^{\mathrm{e}} \\
\left(\mathrm{nm} \mathrm{h}^{-1}\right)\end{array}$ & $\begin{array}{l}\text { Particles } \\
\text { produced }^{\mathrm{f}} \\
\left(\mathrm{cm}^{-3}\right)\end{array}$ & $\begin{array}{c}\text { Cond. } \\
\text { sink }^{\mathrm{g}} \\
\left(10^{-4} \mathrm{~s}^{-1}\right)\end{array}$ & $\begin{array}{c}\text { Vapour } \\
\text { conc. } \\
\left(10^{7} \mathrm{~cm}^{-3}\right)\end{array}$ & $\begin{array}{c}\text { Vapour } \\
\text { source rate } \\
\left(10^{4} \mathrm{~cm}^{-3} \mathrm{~s}^{-1}\right)\end{array}$ \\
\hline \multicolumn{10}{|c|}{ Western air masses at Pallas } \\
\hline Mean & $11: 16$ & 427 & $04: 42$ & 0.10 & 3.0 & 1570 & 5.6 & 5.0 & 3.2 \\
\hline Median & $11: 18$ & 372 & $04: 22$ & 0.08 & 2.7 & 1370 & 3.9 & 4.4 & 1.7 \\
\hline Min & $05: 14$ & 96 & 02:00 & 0.01 & 0.9 & 130 & 1.0 & 1.5 & 0.2 \\
\hline Max & $14: 54$ & 1754 & $08: 25$ & 0.41 & 10.0 & 3840 & 19.8 & 16.3 & 21.5 \\
\hline Stdev & 02:09 & 360 & $01: 41$ & 0.08 & 1.8 & 1120 & 4.8 & 2.9 & 4.3 \\
\hline \multicolumn{10}{|c|}{ Western air masses at Värriö } \\
\hline Mean & $12: 53$ & 744 & $04: 27$ & 0.10 & 3.3 & 1530 & 9.4 & 5.3 & 6.1 \\
\hline Median & $12: 50$ & 678 & $03: 58$ & 0.08 & 2.9 & 1460 & 4.9 & 4.8 & 1.8 \\
\hline Min & 07:03 & 154 & 01:07 & 0.00 & 1.1 & 30 & 0.4 & 1.7 & 0.3 \\
\hline $\operatorname{Max}$ & $16: 28$ & 1867 & 09:00 & 0.54 & 9.0 & 4210 & 40.1 & 14.8 & 59.3 \\
\hline Stdev & $02: 16$ & 496 & 02:08 & 0.10 & 1.7 & 1210 & 11.0 & 2.8 & 11.2 \\
\hline \multicolumn{10}{|c|}{ Eastern air masses at Värriö } \\
\hline Mean & $10: 26$ & 1177 & 03:48 & 0.22 & 4.6 & 2450 & 10.9 & 7.6 & 9.4 \\
\hline Median & $10: 08$ & 1144 & $03: 34$ & 0.07 & 5.3 & 1180 & 6.5 & 8.6 & 5.7 \\
\hline Min & 08:30 & 155 & $02: 26$ & 0.03 & 2.1 & 240 & 1.4 & 3.5 & 0.6 \\
\hline $\operatorname{Max}$ & $14: 18$ & 3348 & $06: 27$ & 0.67 & 7.3 & 6110 & 30.4 & 11.9 & 36.1 \\
\hline Stdev & 02:05 & 1130 & $01: 24$ & 0.27 & 1.8 & 2500 & 11.2 & 2.9 & 12.8 \\
\hline \multicolumn{10}{|c|}{ Eastern air masses at Pallas } \\
\hline Mean & $11: 36$ & 834 & $03: 54$ & 0.13 & 4.1 & 1700 & 15.3 & 6.7 & 11.0 \\
\hline Median & $11: 04$ & 810 & $03: 42$ & 0.10 & 4.3 & 1600 & 13.4 & 7.0 & 8.6 \\
\hline Min & $08: 40$ & 494 & 02:01 & 0.03 & 1.2 & 340 & 6.6 & 1.9 & 1.3 \\
\hline $\operatorname{Max}$ & $14: 50$ & 1537 & $05: 32$ & 0.29 & 6.0 & 3560 & 29.1 & 9.8 & 20.5 \\
\hline Stdev & 02:07 & 348 & $01: 11$ & 0.10 & 1.7 & 1250 & 8.2 & 2.7 & 7.5 \\
\hline
\end{tabular}

${ }^{\text {a }}$ Starting time of 7-nm particle formation; ${ }^{b}$ Pre-existing particle concentration at the time of start; ${ }^{\mathrm{c}}$ Duration of the formation event; ${ }^{\mathrm{d}}$ Formation rate of 7-nm particles; ${ }^{\mathrm{e}}$ Growth rate of newly formed particles; ${ }^{\mathrm{f}} \mathrm{New}$ particles produced during the event; ${ }^{\mathrm{g}}$ Condensation sink for vapour by existing particles; ${ }^{\text {h }}$ Vapour concentration needed for the observed growth; ${ }^{i}$ Vapour source rate needed to sustain the growth.

events were observed to start earlier at the western station Pallas (Fig. 3a). This demonstrates that particle formation in a certain air mass type depends not only on the diurnal variation of the parameters causing the phenomenon (such as photochemistry) but also on some properties carried by the air mass itself. The formation rate of $7 \mathrm{~nm}$ particles showed differences between the two sites on individual days (Fig. 3b), but no systematic pattern can be found. It seems that the particle formation rate is not very conservative parameter in an air mass. On the other hand the correlation in growth rates between the two sites was relatively good (Fig. 3c), which suggests that the amount of condensable vapour causing the growth must have been at about the same level in both sites. It seems that in eastern air masses a bit higher growth rates were observed, probably because they had spent more time over the continent. The condensation sink (CS) was frequently much higher at the downwind station (Fig. 3d). This demonstrates the effect of particle sources and sinks modifying the particle size distribution on the path from one station to the other. It seems that secondary particle formation re- lated to biogenic sources dominates in many cases over the particle sink during the air mass transport between the sites. This is in part evident because new particle formation does not occur on rainy days which would provide an effective sink for the particles.

Table 2 provides parameters classified by the air mass origin for particle formation events observed on the same day in both sites. First we take a look at the western air masses (from Pallas to Värriö) originating mostly from the Atlantic Ocean. When reaching Värriö, these air masses had been influenced more by the continent, which caused a higher preexisting particle concentration and higher condensation sink (CS) compared with Pallas on many days. The formation rate of 7-nm particles (J7) and the growth rate were close to equal in both sites during these western air masses. During western air masses particle formation is starting about $1.5 \mathrm{~h}$ earlier in Pallas than in Värriö, on average.

The eastern air masses (from Värriö to Pallas) were mostly continental and travelled sometimes over the Kola Peninsula industrial area. Värriö is closer to the Kola Peninsula area 

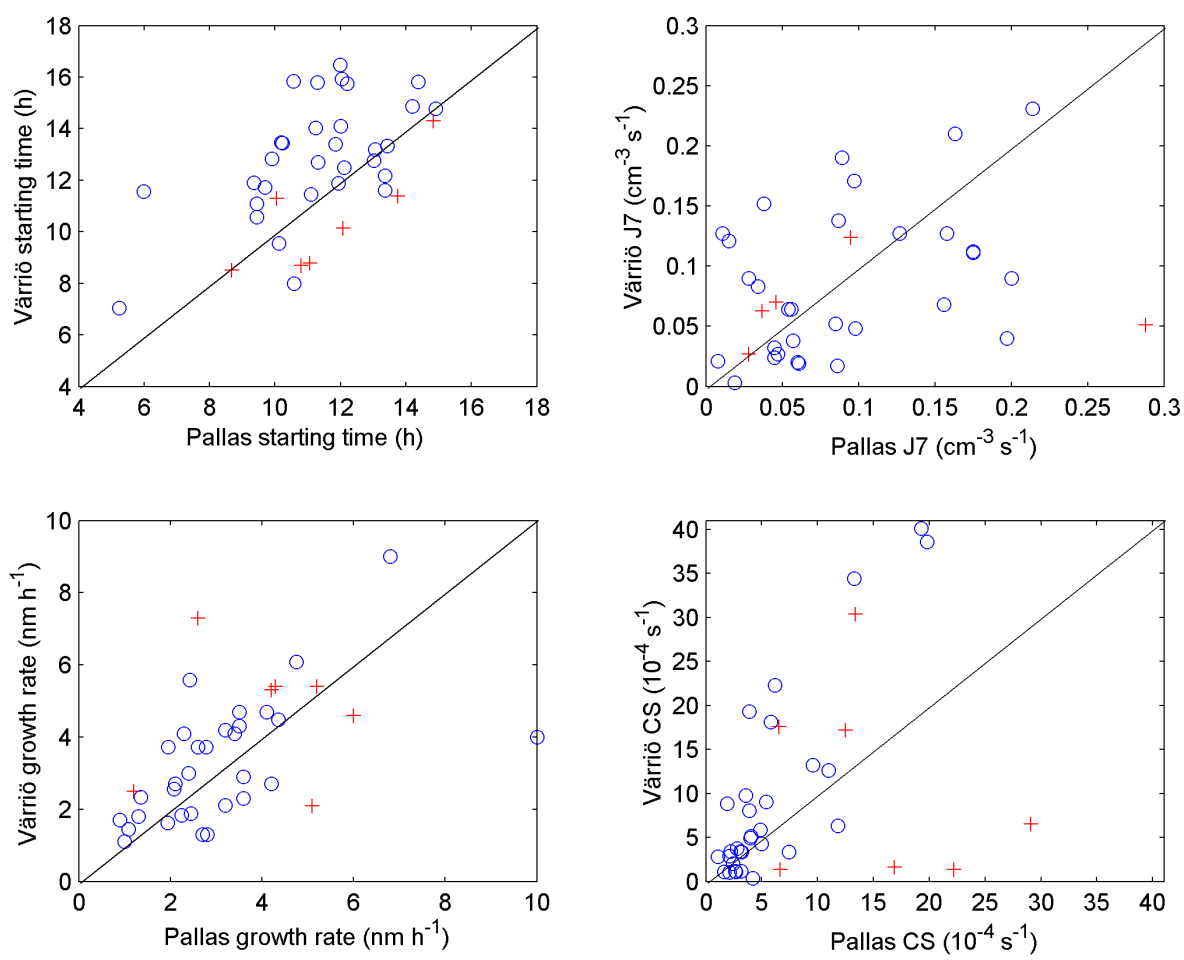

Fig. 3. Comparison of the effect of different air masses on particle formation parameters (blue circles $=$ western and red crosses $=$ eastern). The starting times are exact values and others are averages over each particle formation event.

and is therefore influenced more strongly by the industrial plumes. The oxidation of $\mathrm{SO}_{2}$ to $\mathrm{H}_{2} \mathrm{SO}_{4}$ in these plumes could boost the particle formation in Värriö on some days. This is seen as a higher formation rate of 7-nm particles and also a slightly higher growth rate than in Pallas during the eastern air masses. On average more new particles were produced in Värriö compared to Pallas. This is partly due to a higher CS observed in Pallas during the eastern air masses. Higher concentrations in Pallas refer either to some primary particle sources or to secondary formation of particulate matter between the sites. It seems that during eastern air masses new particle formation is starting $1.2 \mathrm{~h}$ earlier in Värriö than in Pallas, on average.

When looking at the average values on both sites, the eastern air masses had higher pre-existing particle concentrations and CS, compared with western air masses. The eastern air masses had also higher particle formation rates and slightly higher growth rates. Also larger numbers of new particles were produced during eastern air masses compared with western air masses. This requires higher concentrations and source rates of condensable vapour and suggests that on average in continental (eastern) air masses there is more nucleating and condensable vapour available for particle formation and subsequent growth.

\subsection{Case studies}

Two cases of transport from Pallas to Värriö were selected for further analysis. In both cases the air arrived at Pallas from the Arctic Ocean after travelling over land for only 9$10 \mathrm{~h}$. Due to the marine origin and the short interaction time with continental sources, the measured pre-existing particle load and $\mathrm{SO}_{2}$ concentration were relatively low. These cases were also simulated with an aerosol dynamic model UHMA. The air mass trajectory information for the simulations was obtained from Hysplit 4 (Draxler and Rolph, 2003) and the model was initialized with particle size distribution and $\mathrm{SO}_{2}$ measurements made at Pallas.

\subsubsection{Case 1 (30 July 2002)}

As case 1 (Fig. 4), we present an intense new particle formation event with medium background concentration. After a long travel close to the sea surface of the Northern Atlantic (Fig. 5) the air mass travelled over the continent for 9 and $19 \mathrm{~h}$ prior to arrival at Pallas and Värriö, respectively. On this day, new particle formation was observed only at the Värriö station where the event started at 9:00. Prior to the onset of the event the increase of the boundary layer height was observed to dilute the aerosol. The particle growth was strong until 15:00. The measurements in Värriö showed a pre-existing particle concentration of $260 \mathrm{~cm}^{-3}$ and CS of 

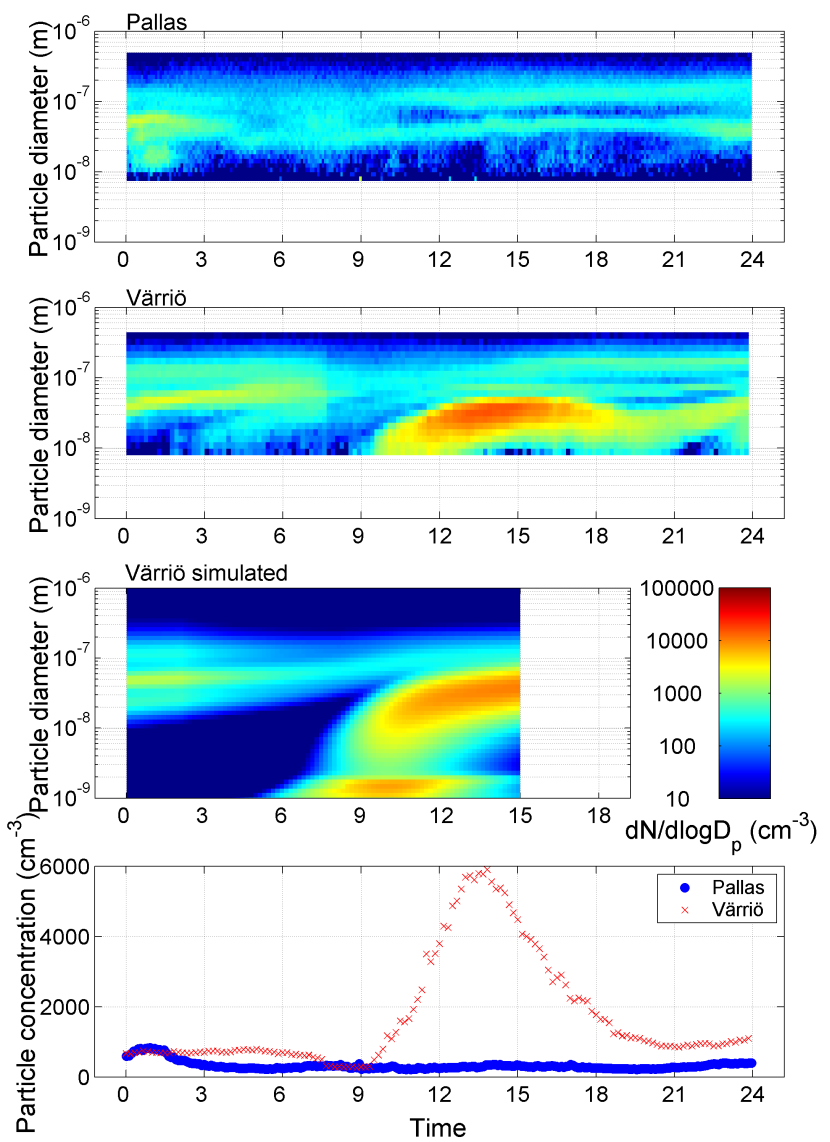

Fig. 4. Case 1: A new particle formation event observed only in Värriö on 30 July 2002.

$3.9 \times 10^{-4} \mathrm{~s}^{-1}$. The formation rate of 7 -nm particles was $0.33 \mathrm{~cm}^{-3} \mathrm{~s}^{-1}$ and the particle growth rate was $5.6 \mathrm{~nm} \mathrm{~h}^{-1}$. Approximately $5400 \mathrm{~cm}^{-3}$ new particles were produced during this relatively intense event. The fact that no event was observed at Pallas could not be explained by weather data as the weather parameters were very similar to those at Värriö.

Figures 4 and 6 display the simulation results for this day. Despite the intensity of the observed event, model simulations show that the nucleation rate could not have been close to the kinetic limit on this day. The appropriate intensity of the event can be reproduced using a scaling factor of $2 \times 10^{-4}-6 \times 10^{-3}$ for the kinetic nucleation rate, the exact value depending on the production profile of the low-volatile organics, which makes the main contribution for the growth. Using these scaling factors for kinetic nucleation the maximum nucleation rate was $1-4 \mathrm{~cm}^{-3} \mathrm{~s}^{-1}$. This relatively slow nucleation rate was able to produce a high concentration of new particles because of the low pre-existing particle load which was further diluted due to a boundary layer increase during the morning hours.

Based on a large number of model runs, it was observed that in order to reproduce an event similar to our measure- ments, the concentration of condensable organics had to increase during the day. A production profile proportional to the $\mathrm{OH}$ concentration gave the best result; this is supported by the assumption that condensable organic vapours are likely to result from $\mathrm{OH}$-oxidation reactions of terpenes. The concentration profiles of condensable organics and sulphuric acid during the simulation are presented in Fig. 7. The same growth rate as in the measurements was achieved using a maximum organic concentration of $1.2 \times 10^{8} \mathrm{~cm}^{-3}$. In this simulation the maximum sulphuric acid concentration was approximately $2 \times 10^{6} \mathrm{~cm}^{-3}$, so sulphuric acid made only a minor contribution to the growth.

The separate "mode" that appears below $3 \mathrm{~nm}$ in the simulated distributions (Figs. 4 and 8) deserves a few words: Due to efficient coagulation with bigger particles, only a small fraction of the large number of clusters $<3 \mathrm{~nm}$ survives to the actual nucleation mode sizes and continue growing. Along with the growth of the nucleation mode, the condensation and coagulation sinks of the particle population increase leading to increasing coagulation loss for the freshly nucleated clusters. At some stage, the coagulation sink for clusters becomes big enough to suppress the feeding of new particles to the growing nucleation mode, which leads to a cease of the nucleation burst. However, the growth of the nucleation mode continues also after the feeding of new particles is stopped.

\subsubsection{Case 2 (8 May 2003)}

Case 2 represents an event in a clean air mass with low background concentrations (Fig. 8). On this day, new particle formation was observed at about the same time at both sites. The formation of new 3-nm particles started at 09:00 in Värriö, whereas the formation of 7-nm particles started around 11:00 at both sites. This event was characterized by a slow and long particle growth until midnight. An increase in the boundary layer height was observed in the morning. On this day the air mass came from the north and circulated over the Arctic Ocean (Fig. 9). Before entering the continent, the air travelled close to the sea surface keeping the air relatively clean and the particle concentration low. The air mass arrived at Pallas after spending $10 \mathrm{~h}$ over the continent and travelled further $9 \mathrm{~h}$ before arrival to Värriö.

The pre-existing particle concentration before the event was around $100 \mathrm{~cm}^{-3}$ at Pallas and $400 \mathrm{~cm}^{-3}$ at Värriö. The condensation sink was slightly higher in Pallas $\left(2.8 \times 10^{-4} \mathrm{~s}^{-1}\right)$ than in Värriö $\left(1.3 \times 10^{-4} \mathrm{~s}^{-1}\right)$ despite the lower pre-existing particle concentration in Pallas. The formation rate of $7-\mathrm{nm}$ particles was close to equal, being $0.03 \mathrm{~cm}^{-3} \mathrm{~s}^{-1}$ in Värriö and $0.02 \mathrm{~cm}^{-3} \mathrm{~s}^{-1}$ in Pallas. Particle growth rates were low and close to equal around $1-2 \mathrm{~nm} \mathrm{~h}^{-1}$, but in Värriö the growth continued for a longer period. This particle formation event produced $820 \mathrm{~cm}^{-3}$ new particles in Värriö and $270 \mathrm{~cm}^{-3}$ in Pallas. 


\section{NOAA HYSPLIT MODEL Backward trajectory ending at 07 UTC 30 Jul 02 FNL Meteorological Data}

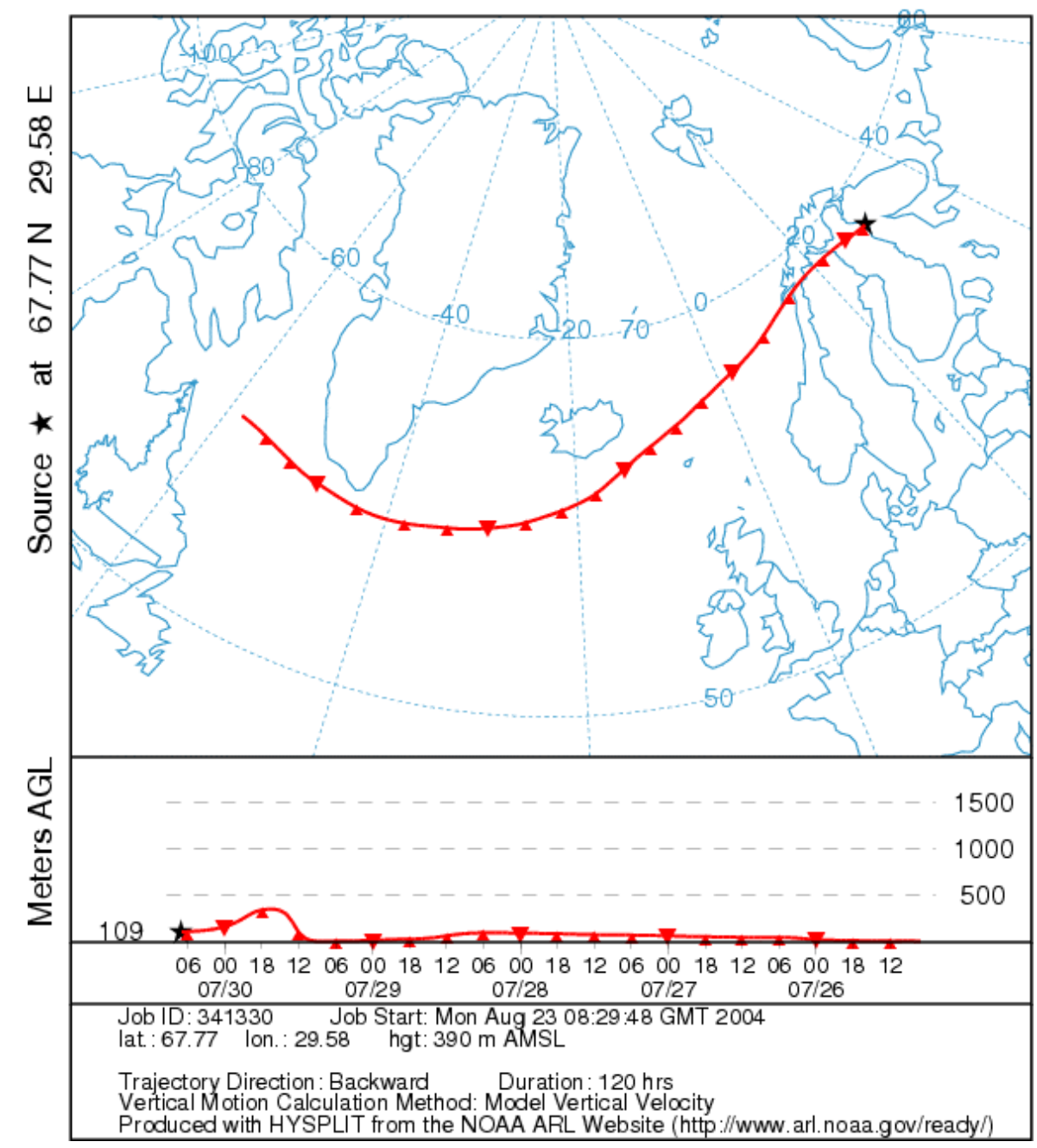

Fig. 5. Case 1: Trajectory path of the air mass, in which the particle formation takes place in Värriö on 30 July 2002.

Simulation results for this case study are presented in Figs. 8 and 10. Even though the event was weak compared to case 1 , the nucleation scaling factor needed to reproduce the observed intensity of the event was of the same order as in case 1. The difference is observed in the concentration of the condensable organic vapour: because the growth of the nucleation mode continued until midnight, the concentration of the organics had to rise or at least stay approximately constant in the night. The best agreement with the measurement was achieved using a constant organic production rate or, more realistically, a production rate that has two small maxima at noon and at midnight, representing oxidation reactions with $\mathrm{OH}$ and $\mathrm{NO}_{3}$. The simulations presented in Figs. 8 and 10 were made with a constant production rate; the resulting concentration profile is shown in Fig. 7.

\subsubsection{Discussion of simulation results}

In both of the cases simulated above, the model was able to reproduce the observed nucleation events at Värriö, $250 \mathrm{~km}$ downwind of the simulation starting point. However, the model runs revealed some differences between the two events. The formation rate of 7-nm particles at Värriö was measured to be approximately ten times higher in case 1 . According to the model simulations, the actual nucleation rate (at around $1 \mathrm{~nm}$ ) was $20-40 \%$ lower in this case. This is due to the fact that in case 1 the pre-existing particle load, or 


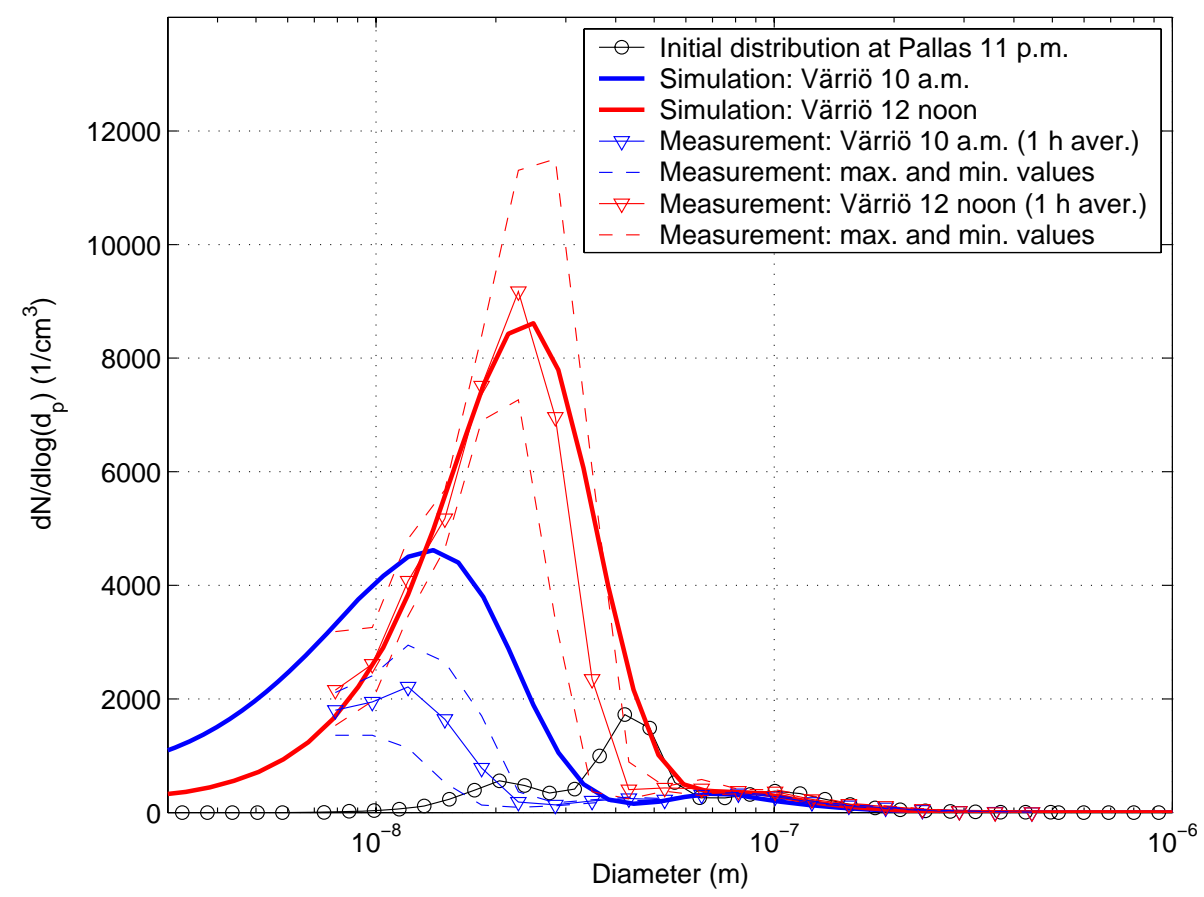

Fig. 6. Simulated and measured size distributions, 30 July 2002.

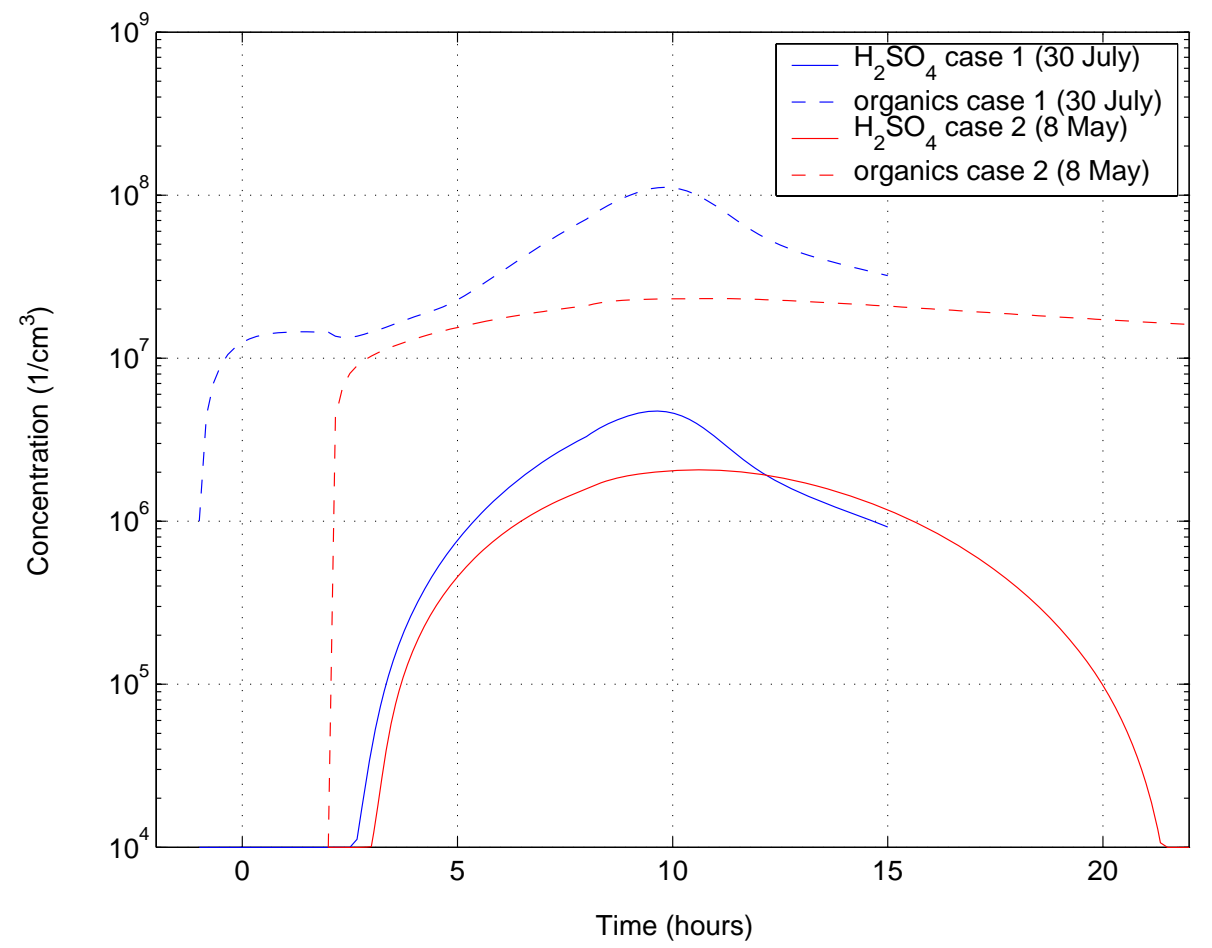

Fig. 7. The used concentration profiles of condensable organics and sulphuric acid during the simulation. 
condensation sink, was significantly lower and the concentration of condensable organic vapour required to reproduce the observed nucleation mode growth rate was higher. These two factors, i.e. slower scavenging to pre-existing aerosol and faster growth rate of new particles, made it possible for a larger fraction of the newly formed particles to survive to detectable sizes.

In case 1 , the simulated nucleation rates was three to four orders of magnitude lower than the calculated kinetic limit whereas in case 2 we had to assume a scaling factor larger than $10^{-3}$; the exact value of the scaling factor is dependent on the simulated organic vapour concentration. The condensable organic vapours were assumed to form in oxidation reactions of forest emitted terpenes. The organic concentration profiles that best reproduced the observations at the receptor site Värriö were different in the two cases indicating that divergent formation reactions may dominate under different conditions. This could be due to the fact that the emission rates of the natural organic vapours depend on temperature, radiation or other environmental factors (Kesselmeier and Staudt, 1999), or that the oxidation mechanisms leading to low-volatile end products are highly complicated.

In the selected cases, the simulated concentrations of sulphuric acid explained less than $10 \%$ of the nucleation mode growth, indicating that organic compounds are the main contributor to particle growth in this clean yet relatively sparsely vegetated subarctic environment. This observation is also in line with earlier analyses for more densely vegetated environments (Birmili et al., 2003; Boy et al., 2005). The crucial role of organics in new particle growth offers a tentative hypothesis to the distinct features of new particles at the two sites: At the source station Pallas no particle formation at $7 \mathrm{~nm}$ is detected in case 1 and in case 2 the growth of formed particles is not as clear as at Värriö. Since the air mass in both cases reaches Pallas after travelling over land for only 9-10 h, the time for the organic vapours to accumulate in the air and to interact with the particles is relatively short. As a result, the growth rate of newly formed clusters remains low, they are effectively scavenged by pre-existing particles and may not reach the detection limit of the measurement instrumentation.

\section{Conclusions}

Four years of aerosol number size distribution data was used in this study. Two years of new data from years 2002-2003 were also examined. During the years 2002-2003 over 100 new particle formation events were observed. More than half of the events were observed to occur on the same day in a scale of $250 \mathrm{~km}$. The highest frequency of events occurred in April and September. The slightly higher average values of particle formation and growth rates observed in Värriö site refer to polluted events boosted by the Kola Peninsula industrial area. Overall the values were of the same magnitude as observed in earlier studies.
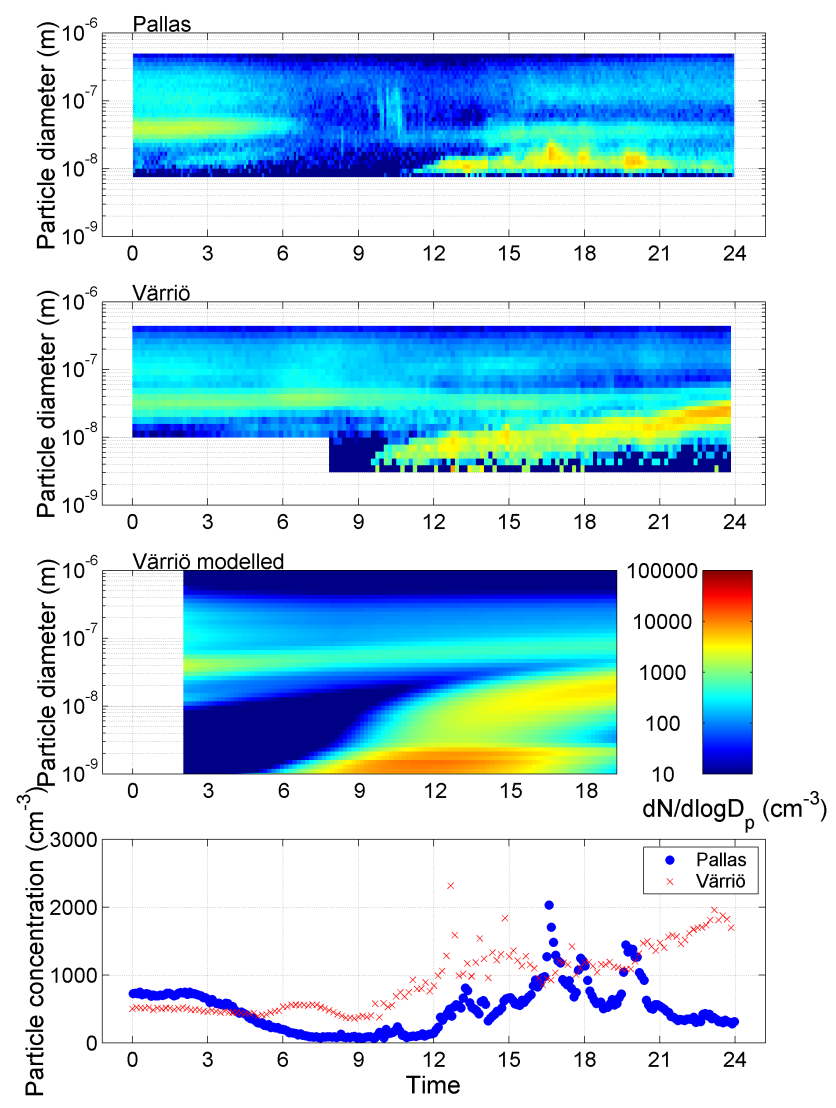

Fig. 8. Case 2: A new particle formation event observed at both sites on 8 May 2003.

A clear seasonal variation was found in the starting time of the events, following the annual pattern of sun rise. The particle formation rate had higher values in Värriö from March to July, possibly due to more frequent polluted air masses from the Kola Peninsula industrial area. No clear seasonal pattern in the formation rate of 7-nm particles was observed. The particle growth rate showed a clear seasonal variation, the values being highest in summer. These results are in agreement with earlier studies.

A comparison of parameters related to particle formation at two sites in both western and eastern air masses was presented. In eastern air masses almost all events were observed to start earlier at the eastern station Värriö, whereas in western air masses most of the events were observed to start earlier at the western station Pallas. This demonstrates that particle formation in a certain air mass type depends not only on the diurnal variation of the parameters causing the phenomenon (like photochemistry) but also on some properties carried by the air mass itself. The formation rate of 7-nm particles showed differences between the two sites, but without a systematic pattern. It seems that the particle formation rate is not a very conservative parameter in an air mass. The correlation in growth rates between the two sites was relatively 


\section{NOAA HYSPLIT MODEL Backward trajectory ending at 07 UTC 08 May 03 FNL Meteorological Data}

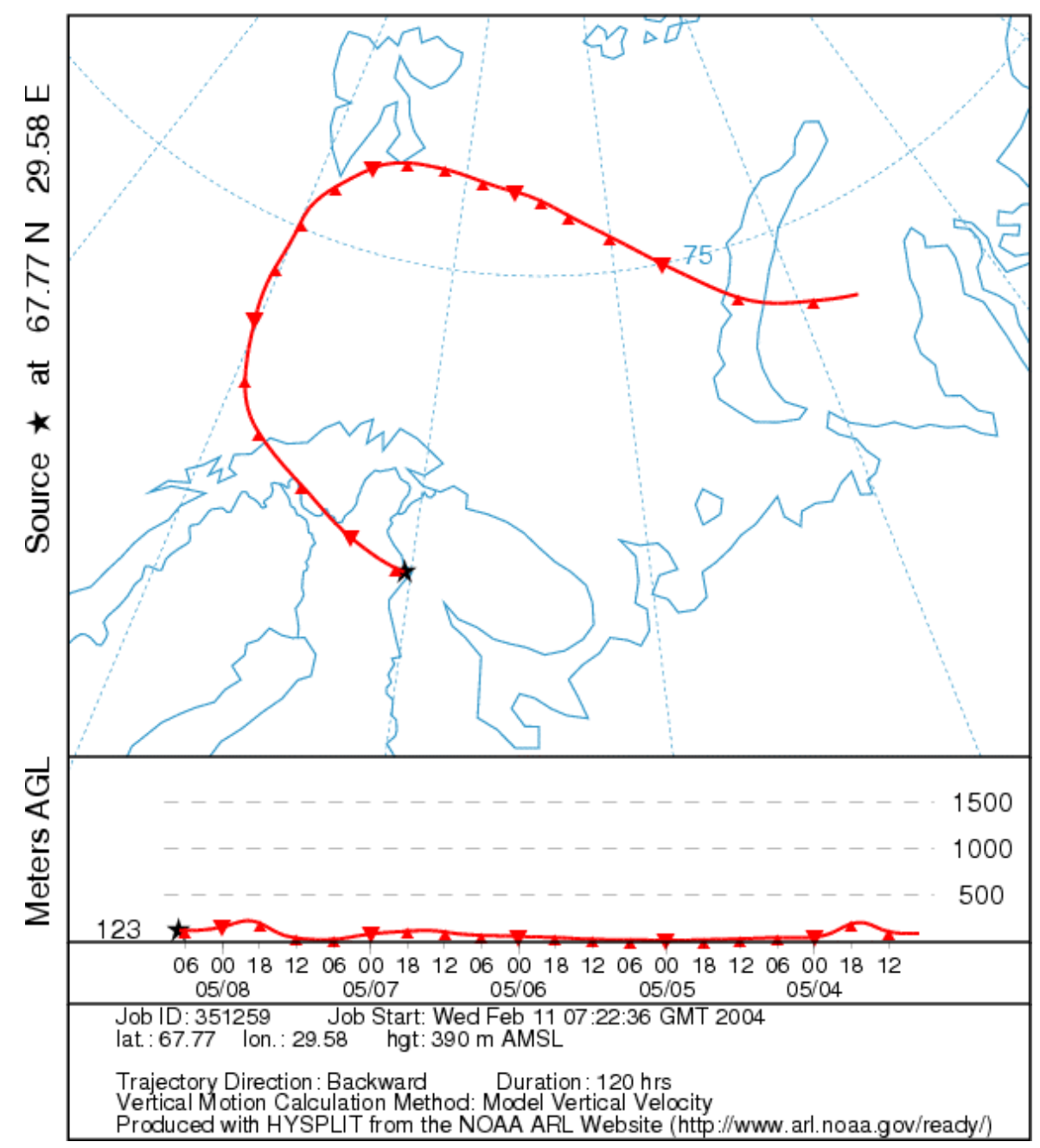

Fig. 9. Case 2: Trajectory path of the air mass, in which the particle formation takes place in Värriö on 8 May 2003.

high, which suggests that the amount of condensable vapour causing the growth must have been at about the same level in both sites. The condensation sink (CS) was frequently much higher at the downwind station. It seems that secondary particle formation related to biogenic sources dominate in many cases over the particle sinks during the air mass transport between the sites.

In western (marine) air masses the formation and growth rates were close to equal in both sites on average. During western air masses emissions are mainly biogenic, therefore Värriö (deeper in the boreal forest than Pallas) has higher source rates of condensable vapour. However, higher vapour source rates combined with higher condensation sinks compensate each other, which might partly explain why no difference in particle formation and growth rates were observed between Pallas and Värriö in these western air masses. In eastern continental air masses higher formation rates and slightly higher growth rates were observed in Värriö which is closer to the major pollutant sources in Kola Peninsula area. On average, continental air masses had higher formation and growth rates compared to marine air masses. This suggests that in these more polluted continental air masses there is more nucleating and condensable vapour available for particle formation and growth.

Two cases of transport from Pallas to Värriö were selected for further analysis and model simulations were performed along the trajectories on these days. The simulations highlighted the influence of pre-existing particle concentration and condensable vapour concentration on new particle formation. Due to low particle load and high simulated vapour 


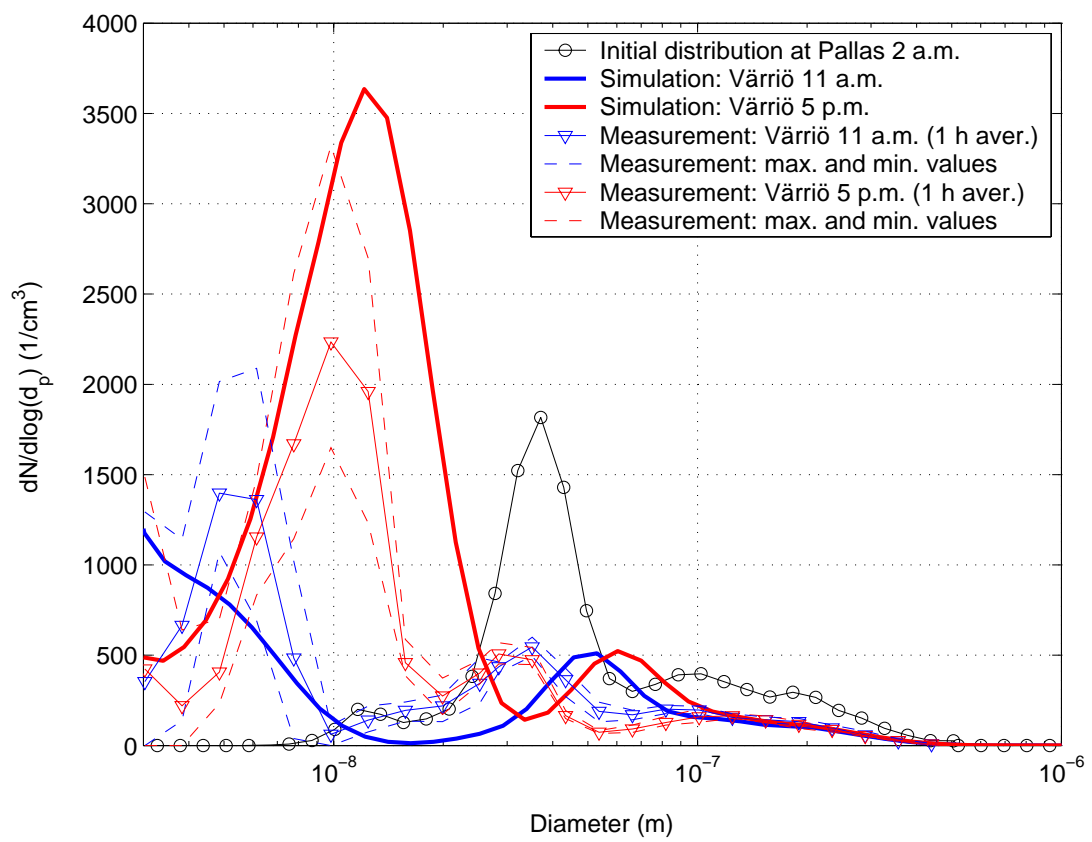

Fig. 10. Simulated and measured size distributions, 8 May 2003.

concentrations, the formation rate of 7-nm particles was approximately ten times higher in case 1 than in case 2 , although the actual nucleation rate (at around $1 \mathrm{~nm}$ ) was 20 $40 \%$ lower in case 1 . The organic concentration profiles that best reproduced the observations at the receptor site Värriö were different in the two cases indicating that divergent formation reactions may dominate under different conditions. This could be due to the fact that the emission rates of the natural organic vapours depend on temperature, radiation or other environmental factors, or that the oxidation mechanisms leading to low-volatile end products are highly complicated.

In the selected cases, the simulated concentrations of sulphuric acid explained less than $10 \%$ of the nucleation mode growth, indicating that organic compounds are the main contributor to particle growth in this clean yet relatively sparsely vegetated subarctic environment. This observation is also in line with earlier analyses for more densely vegetated environments (Boy et al., 2005; Birmili et al., 2003). The crucial role of organics in new particle growth offers a tentative hypothesis to the distinct features of new particles at the two sites: At the source station Pallas no particle formation at $7 \mathrm{~nm}$ is detected in case 1 , and in case 2 the growth of formed particles is not as clear as at Värriö. Since the air mass in both cases reaches Pallas after travelling over land for only 9-10 h, the time for the organic vapours to accumulate in the air and to interact with the particles is relatively short. As a result, the growth rate of newly formed clusters remains low, they are effectively scavenged by pre-existing particles and may not reach the detection limit of the measurement instrumentation.
Acknowledgements. The authors would like to thank the Academy of Finland and the LAPBIAT project for financial support.

Edited by: U. Baltensperger

\section{References}

Adams, P. J. and Seinfeld, J. H.: Predicting global aerosol size distributions in general circulation models, J. Geophys. Res., 107(D19), 4370, doi:10.1029/2001JD001010, 2002.

Ahonen, T., Aalto, P., Rannik, Ü., Kulmala, M., Nilsson, E. D., Palmroth, S., Ylitalo, H., and Hari, P.: Variations and vertical profiles of trace gas and aerosol concentrations and $\mathrm{CO}_{2}$ exchange in eastern Lapland, Atmos. Environ. 31, 3351-3362, 1997.

Birmili, W., Berresheim, H., Plass-Dalmer, C., Elste, T., Gilge, S., Wiedensholer, A., and Uhrner, U.: The Hohenpeissenberg aerosol formation experiment (HAFEX): a long term study including size-resolved aerosol, $\mathrm{H}_{2} \mathrm{SO}_{4}, \mathrm{OH}$, and monoterpene measurements, Atmos. Chem. Phys., 3, 361-376, 2003, http://www.atmos-chem-phys.net/3/361/2003/.

Boy, M., Kulmala, M., Ruuskanen, T. M., Pihlatie, M., Reissell, A., Aalto, P. P., Keronen, P., Dal Maso, M., Hellen, H., Hakola, H., Jansson, R., Hanke, M., and Arnold, F.: Sulphuric acid closure and contribution to nucleation mode particle growth, Atmos. Chem. Phys., 5, 863-878, 2005, http://www.atmos-chem-phys.net/5/863/2005/.

Draxler, R. R. and Rolph, G. D.: HYSPLIT (HYbrid Single-Particle Lagrangian Integrated Trajectory) Model access via NOAA ARL READY Website (http://www.arl.noaa.gov/ready/hysplit4.html), NOAA Air Resources Laboratory, Silver Spring, MD, 2003.

Grini, A., Korhonen, H., Lehtinen, K. E. J., Isaksen, I. S. A., and Kulmala, M.,: A combined photochemistry/aerosol dynamics model: Model development and a study of new particle formation, Boreal Env. Res., 10, 525-541, 2005. 
Hatakka, J., Aalto, T., Aaltonen, V., Aurela, M., Hakola, H., Komppula, M., Laurila, T., Lihavainen, H., Paatero, J., Salminen, K., and Viisanen, Y.: Overview of the atmospheric research activities and results at Pallas GAW station, Boreal Env. Res., 8(4), 365-384, 2003.

Hari, P., Kulmala, M., Pohja, T., Lahti, T., Siivola, E., Palva, L., Aalto, P., Hämeri, K., Vesala, T., Luoma, S., and Pulliainen, E.: Air pollution in Eastern Lapland: Challenge for an Environmental Measurement Station, Silva Fennica, 28, 29-39, 1994.

Jacobson, M. Z.: Global direct radiative forcing due to multicomponent anthropogenic and natural aerosols, J. Geophys. Res., 106, 1551-1568, 2001.

Jokinen, V. and Mäkelä, J. M.: Closed-loop arrangement with critical orifice for DMA sheath/excess flow system, J. Aerosol Sci., 28, 643-648, 1997.

Kaufman, Y. J., Tanre, D., and Boucher, O.: A satellite view of aerosols in the climate system, Nature, 419, 215-223, 2002.

Kavouras, I., Mihalopoulos, N., and Stephanou, E. G.: Formation and gas/particle partitioning of monoterpene photo-oxidation products over forests, Geophys. Res. Lett., 26, 55-59, 1998.

Kerminen, V.-M., Lihavainen, H., Komppula, M., Viisanen, Y., and Kulmala, M.: Direct observational evidence linking atmospheric aerosol formation and cloud droplet activation, Geophys. Res. Lett., 32, L14803, doi:10.1029/2005GL023130, 2005.

Kesselmeier, J. and Staudt, M.: Biogenic volatile organic compounds (VOC): An overview on emission, physiology and ecology, J. Atm. Chem., 33, 23-87, 1999.

Komppula, M., Lihavainen, H., Hatakka, J., Aalto, P. P., Kulmala, M., and Viisanen Y.: Observations of new particle formation and size distribution at two different heights and surroundings in subarctic area in Northern Finland, J. Geophys. Res., 108(D9), 4295, doi:10.1029/2002JD002939, 2003a.

Komppula, M., Dal Maso, M., Lihavainen, H., Aalto, P. P., Kulmala, M., and Viisanen, Y.: Comparison of new particle formation events at two locations in northern Finland, Boreal Env. Res., 8(4), 395-404, 2003b.

Komppula, M, Lihavainen, H., Kerminen, V.-M., Kulmala, M., and Viisanen, Y.: Measurements of cloud droplet activation of aerosol particles at a clean subarctic background site, J. Geophys. Res., 110, D06204, doi:10.1029/2004JD005200, 2005.

Korhonen, H., Lehtinen, K. E. J., and Kulmala, M.: Multicomponent aerosol dynamics model UHMA: model development and validation, Atmos. Chem. Phys., 4, 757-771, 2004, http://www.atmos-chem-phys.net/4/757/2004/.

Korhonen, H., Kerminen, V.-M., Lehtinen, K. E. J., and Kulmala, M.: CCN activation and cloud processing in sectional aerosol models with low size resolution, Atmos. Chem. Phys., 5, 25612570, 2005,

http://www.atmos-chem-phys.net/5/2561/2005/.

Kourtchev, I., Ruuskanen, T., Maenhaut, W., Kulmala, M., and Claeys, M.: Observation of 2-methyltetrols and related photooxidation products of isoprene in boreal forest aerosols from Hyytiälä, Finland, Atmos. Chem. Phys., 5, 2761-2770, 2005, http://www.atmos-chem-phys.net/5/2761/2005/.

Kulmala, M., Toivonen, A., Mäkelä, J., and Laaksonen, A.: Analysis of the growth of nucleation mode particles observed in boreal forest, Tellus, Ser. B, 50, 449-462, 1998.

Kulmala, M., Dal Maso, M., Mäkelä, J., Pirjola, L., Väkevä, M., Aalto, P., Miikkulainen, P., Hämeri, K., and O’Dowd, C. D.: On the formation, growth and composition of nucleation mode particles, Tellus, Ser. B, 53, 479-490, 2001.

Kulmala, M., Vehkamäki, H., Petäjä, T., Dal Maso, M., Lauri, A., Kerminen, V.-M., Birmili, W., and McMurry, P. H.: Formation and growth rates of ultrafine atmospheric particles: A review of observations, J. Aerosol Sci., 35, 143-176, 2004a.

Kulmala, M., Kerminen, V.-M., Anttila, T., Laaksonen, A., and O'Dowd C.D.: Organic aerosol formation via sulphate cluster activation, J. Geophys. Res., 109(D4), 4205, doi:10.1029/2003JD003961, 2004b.

Lihavainen, H., Kerminen, V.-M., Komppula, M., Hatakka, J., Aaltonen, V., Kulmala, M., and Viisanen, Y.: Prodution of "potential" cloud condensation nuclei production associated with atmospheric new-particle formation in northern Finland, J. Geophys. Res., 108(D24), 4782, doi:10.1029/2003JD003887, 2003.

Lohmann, U. and Feichter, J.: Global indirect aerosol effects: a review, Atmos. Chem. Phys., 5, 715-737, 2005, http://www.atmos-chem-phys.net/5/715/2005/.

Mauldin, III R. L., Cantrell, C. A., Zondlo, M. A., Kosciuch, E., Ridley, B. A., Weber, R., and Eisele, F. E.: Measurements of OH, $\mathrm{H}_{2} \mathrm{SO}_{4}$, and MSA during tropospheric ozone production about the spring equinox (TOPSE), J. Geophys. Res., 108(D4), 8366, doi:10.1029/2002JD002295, 2003.

Mäkelä, J. M., Aalto, P., Jokinen, V., Pohja, T., Nissinen, A., Palmroth, S., Markkanen, T., Seitsonen, K., Lihavainen, H., and Kulmala, M.: Observations of ultrafine aerosol particle formation and growth in boreal forest, Geophys. Res. Lett., 24, 1219-1222, 1997.

Mäkelä, J., Dal Maso, M., Pirjola, L., Keronen, P., Laakso, L., Kulmala, M., and Laaksonen, A.: Characteristics of the atmospheric particle formation events observed at a boreal forest site in Southern Finland, Boreal Env. Res., 5, 299-313, 2000.

Pirjola, L., Kulmala, M., Wilck, M., Bischoff, A., Stratmann, F., and Otto, E.: Effects of aerosol dynamics on the formation of sulphuric acid aerosols and cloud condensation nuclei, J. Aerosol Sci., 30, 1079-1094, 1999.

Seinfeld, J. H. and Pandis, S. N.: Atmospheric chemistry and physics: From air pollution to climate change. John Wiley \& Sons Inc, New York, 1998.

Stohl, A., Wotawa, G., Seibert, P., and Kromp-Kolb, H.: Interpolation errors in wind fields as a function of spatial and temporal resolution and their impact on different types of kinematic trajectories, J. Appl. Meteor., 34, 2149-2165, 1995.

Vehkamäki, H., Dal Maso, M., Hussein, T., Flanagan, R., Hyvärinen, A., Lauros, J., Merikanto, J., Mönkkönen, P., Pihlatie, M., Salminen, K., Sogacheva, L., Thum, T., Ruuskanen, T. M., Keronen, P., Aalto, P. P., Hari, P., Lehtinen, K. E. J., Rannik, Ü., and Kulmala, M.: Atmospheric particle formation events at Värriö measurement station in Finnish Lapland 1998-2002, Atmos. Chem. Phys., 4, 2015-2023, 2004, http://www.atmos-chem-phys.net/4/2015/2004/.

Weber, R. J., Marti, J. J., McMurry, P. H., Eisele, F. L., Tanner, D. J., and Jefferson, A.: Measurements of new particle formation and ultrafine particle growth rates at a clean continental site, J. Geophys. Res., 102(D4), 4375-4385, 1997.

Winklmayr, W., Reischl, G. P., Linder, A. O., and Berner, A.: A new electromobility spectrometer for the measurement of aerosol size distribution in the size range 1 to $1000 \mathrm{~nm}$, J. Aerosol Sci., 22, 289-296, 1991. 